\title{
Study Phenomenography (Phenomenographic Approach) Towards Trauma Healing Patterns on Community Conflict Victims in the Slope of Merapi Merbabu in Boyolali
}

\author{
Ba'in $^{1, *}$ Suyahmo ${ }^{2,}$ Suwito Eko Pramono ${ }^{3,}$ Hamdan Tri Atmaja ${ }^{4}$ \\ ${ }^{1}$ Doctoral Students of Study Program of Social Sciences Education, Postgraduate of Universitas Negeri Semarang \\ ${ }^{2}$ Department of Civic Education, Faculty of Social Sciences, Universitas Negeri Semarang \\ ${ }^{3}$ Department of History, Faculty of Social Sciences, Universitas Negeri Semarang \\ ${ }^{4}$ Department of History, Faculty of Social Sciences, Universitas Negeri Semarang \\ ${ }^{*}$ Corresponding author. Email: bain@mail.unnes.ac.id,
}

\begin{abstract}
The area around the slopes of Mount Merapi Merbabu where there are still dense forests, deep ravines, steep slopes, quiet and far from the reach of the authorities was used as a hiding place and a place for the center of the movement of security hordes and rebels. The population around the forest was mostly made up of peoples who are not educated and economically, or religiously weak, so it was easy to be persuaded to help the troublemakers and rebels. Therefore, in this area there are a lot of complex and prolonged conflicts happened, ranging from Suradi Bledeg's benggol actions in 1950 to social conflicts and political conflicts before G30 S. Incident and after the G30 S. Incident. Many residents in this area had lost property and lost family members, and loss of security and peace. They experienced acute social trauma. Departing from such realities, an appropriate trauma healing pattern is needed, so that their lives will return to normal so that they can carry out their roles as citizens and good citizens.

The purpose of this research is oriented to the development of theories in social and political studies with historical settings and conflict resolution. With a specific target, a description of the social trauma caused by the conflict is obtained and taken with the healing patterns found or the appropriate trauma healing model for victims of social and political conflict.

The research method used is based on interpretative / qualitative paradigms that are studied based on phenomenography studies. This study emphasizes variations in empirical experience from informants involved directly or indirectly in conflict events. Data was collected through in-depth interviews, focus group discussions and literature review. The data analysis used is thematic data analysis.

The results of this study include two findings: the first form in the first year the level of knowledge of social trauma informants (figures and community members) and the second form in the second year in the form of a trauma healing model for conflict victims. Further development of this model can be adopted by interested parties (government and community empowerment NGOs) to deal with similar problems in other areas or that occur in the future. The findings of this study will be proposed to obtain a simple patent and be published at national seminars, national journals and international journals.
\end{abstract}

Keywords: Phenomenography, Trauma Healing, Victims of Conflict.

\section{PRELIMINARY}

The ethnic, religious, racial, and cultural diversity, as well as a population of more than 260 million people owned by the Indonesian state, on the one hand make a positive contribution in efforts to create community welfare [1]. However, on the other hand, diversity is accompanied by increasingly rapid social and political dynamics, placing Indonesia as one of the conflict-prone countries, both horizontal and vertical conflicts [2]. The problems underlying social conflict in Indonesia include issues related to ideology, 
politics, economics, social, culture, Ethnic, Religion, Race and Intergroup issues, and land disputes [3].

The definition of conflict, when viewed from the point of view of Javanese society, is a condition that disturbs social harmony [4]. Social harmony is one of the important aspect in maintaining relationships [5] with a cosmological orientation, namely a view of the two cosmos, namely the macrocosm and microcosms [6]. The cosmological view has an influence on every behavior of Javanese people, which is always guided by the balance of the two cosmos in order to obtain peace and safe. Conflicts that occur can be in the form of disputes, tensions, riots, rebellions are often expressed through means of anger, violence, kidnapping, murder [7].

Whatever social conflict takes place because of social and political conflict, the consequences will always be the same, namely social stress, bitterness, social disintegration which is often accompanied by the destruction of various material and non-material assets. The most obvious destruction of non-material assets is found in the form of "decapitalization" of social capital, which is characterized by the loss of trust between the parties, the destruction of networking, and the loss of compliance with the norms and social arrangements that have been mutually agreed upon. same. As if everything that had been painstakingly built and upheld by each of the warring citizens, was easily ended just because of social conflict.

Many peoples had been traumatized because of this conflict. To prevent more severe psychosocial problems and deal with mass trauma, a trauma handling programs for victims of social and political conflict is necessary. Handling of trauma problems usually uses a mental health intervention approach such as multisession treatments. From various metaanalysis studies, there are positive effects of mental health intervention in improving mental condition of individuals [8], both those using certain theoretical approaches, or group or individual approaches. However, clinical approaches to managing trauma are usually more suitable for cases with a small number of subjects. While handling trauma cases experienced by many subjects and prioritizing wider community involvement is more appropriate using a community approach [9].

Observing all that, it turns out that the research on trauma healing that had been experienced by the people in the slopes of Merapi Merbabu Boyolali has not been done much. Moreover, if the study is conducted using the phenomenography approach is a relatively new study in the realm of social and political sciences.
The article which is the result of this research discussion (1) the historical background of social conflicts in the slopes of Merapi Merbabu, Boyolali, (2) psychosocial problems and trauma experienced by communities in the slopes of Merapi Merbabu, Boyolali due to social and political conflicts, and (3) trauma healing that has been accepted and carried out by the community on the slopes of Merapi Merbabu, Boyolali.

\section{THEORY REVIEW}

In simple terms, trauma is an emotional wound that causes memories and emotions that relatively haunt a person's life journey. It is called social trauma because social-psychologically, it causes suffering for many people who experienced the same traumatic incident together. Alexander, Eyerman, and Giesen [10] suggest that there are four dimensions to validate a social trauma. The four dimensions are:

a. Natural characteristics of the pain experienced.

b. Characteristics of the survivors of the group who were targeted and experienced suffering.

c. The relationship between trauma victims and the wider community.

d. Attribution of responsibility: who was the perpetrator who caused the trauma?

The traumatic social memories from various parties in the conflict has the opportunity to be expressed, recognized and juxtaposed as a form of "monument", a common warning so that similar conflicts are not going to happen again in the future. Through this form, the expressed articulation and the narrative that is formed to get public recognition. This allows all those involved in past events to move forward in facing and accepting the past. Indirectly, this too can help release the burden of the past [11].

Trauma healing is closely related to building or improving human relationships which are related to reducing feelings of loneliness, improving mental health, understanding the meaning of peace, reducing feelings of isolation, hatred, and dangers that occur in interpersonal relationships [12]. The people who have experienced trauma needs help to find a new normal life again Rothbaum, explained that recovery treatment for prolonged trauma through cognitive therapy is more effective than using drugs such as reuptakeserotonin or than no recovery treatment in preventing post -traumaticstress disorder. In addition, he also stated that post-traumatic stress disorder (PTSD) treatment and prevention can be done by eliminating fear from traumatic stimuli by replacing it with other stimuli [13]. Daniel Goleman explained that keeping worrying emotions under control is the key to emotional well-being, because of the excessive emotions that are increasing with too much high and long intensity will destabilize mankind [14] . 
Baranowsky \& Lauer [15] explained 3 steps for trauma healing, namely (1) trying to find comfort, (2) recognizing triggers for emotional and physical discomfort, and (3) starting a new life again. To protect traumatized people because of prolonged warfare, Stradling suggests several aspects. First, increase sensitivity, recognize trauma symptoms in traumatized people with gentle and compassionate, empathetic, and conscientious care, and offer the help that they need. Second, ask traumatized people to recount traumatic events that they have experienced. Third, provide consultation or guidance to relieve stress in people who have experienced trauma. Fourth, helping traumatized people to start a new life again.

\section{RESEARCH METHODS}

This research is theoritical and will be implemented in two stages. The first stage is the researcher carried out field research activities by way of a phenomenography approach in the qualitative domain. In this stage, the researcher went straight to the target of the Merapi Merbabu Boyolali mountain slope community with 12-25 informants who were selected purposively. At this initial stage, field data is needed in order to find out the level of knowledge and types of social trauma that have occurred and are still occurring in the community. Data collection techniques chosen were through in-depth interviews (in-depth interviews), focus group discussions (FGD) and documentary studies. Data analysis was carried out thematically (thematical analysis) according to the phases of the phenomenography study analysis.

Second Stage, based on the results of the field research, a community-based trauma healing model will be made. This model is used as a means of prevention or a trauma healing strategy if the community that is prone to social conflict is experiencing trauma due to the conflict both now and in the future.

In this article all of them are the results of the first phase of research which more often presents field research data. For trauma healing models that are designed based on the findings of field research data will be presented in another different article.

Based on data collected in the pre-observation stage, revised interview protocol according to the subject and object of the study, in-depth interviews and focus group discussions (FGD) to the target group and study documents as supplementary data and then analyzed with thematic analysis, the findings are obtained research as described below.

\section{RESEARCH RESULTS AND DISCUSSION \\ 4.1. Social Conflicts That Have Occurred}

The violances in Indonesia is also developing in Central Java. Boyolali is no different from other areas where there are jawara - who master the martial arts and other mystical

sciences. The difference is, people who resemble jawara in Boyolali are more disturbing for the civilian population. They are more often called bandits. During the revolution they were part of the so-called warriors. Later they were disappointed because of the rationalization that removed the armed forces from the Armed Forces.

They ran away and became bandits. One of the many bandits is Suradi Bledeg. Suradi was born in 1921 in Musuk, Boyolali. From the beginning Suradi was interested in studying magic, when Suradi lived in the Simo area. Not satisfied with just studying at Simo, Suradi traveled to Madiun, Kediri, Kedu and Gunung Kidul to deepen their knowledge. He went on pilgrimages to the sacred tombs to live as an ascetic.

Suradi was tall and big, brown-skinned, had black hair and sharp eyes. His face was classified as frightening. The Accessories attached to his body are wide belts and several rings with agate on his fingers. His voice is loud like thunder, making it called Bledeg. Suradi's figure was so fierce and knowledgeable that made his bandit friends appoint him as the leader. Suradi entered MMC - known as the image as a group of bandits - in addition to carrying out acts of bondage, also because of his disappointment over the existence of rationalization in the military.

Previously, Suradi had also joined the people's army in Boyolali. Rationalization, which was planned to reduce the number of troops so that they could be supported to become professional soldiers, was small but effective, had to make the working class unemployed, including Suradi Bledeg. Former unemployed soldiers, of course, become a problem in society. They are accustomed to holding weapons and familiar with the noise and the tension of war. Usually they faced the Dutch Army. If not, they will also be noisy with the army.

Disappointment towards the Republic of Indonesia also made them try to undermine the authority of the government by carrying out various acts of unrest. MMC did it around Mount Merapi and Merbabu in Boyolali and its surroundings. They ransacked people's homes and often committed killings to create terror among civilians who were part of the Republic. Their target, aside from ordinary civilians, is the court, wealthy people, Chinese people and, of course, civil servants who are close to 
the government. Their action took place fiercely between 1950 and 1955. Suradi Bledeg was the most legendary MMC leader in recorded history. Suradi became the leader of the MMC between 1949 and 1951. In 1951, Suradi was killed in Klaten. The next prominent MMC leader was Umar Greece. Although there are many communists who float, not all the communists who carry out the drills belong to the MMC.

With the rationalization in the army that had implications for the MMC made Boyolali a Red-based city. MMC (Merapi Merbabu Complex) are people who are hurt because of the rationalization in the army. In their refusal they exiled themselves to the slopes of Mount Merapi and Merbabu. After Sukarno appealed to the exiled troops to return, there were some people who were willing to surrender and return their weapons to the state. There were also those who remained in exile so they joined the Garong group and were used by the group to carry out the robbery known as the Grayak - Hunger People's Movement (Interview with Marno and Sukardi, 25 September 2019).

Grayak, a scourge of the Boyolali community and its surroundings, leaves its own memories for the history of the city of milk. The band which is famous for its sadism, looting is considered to be the culprit of the PKI forces in Boyolali. So that after the issue of the PKI rebellion, the movement which had been considered only as a movement of the garong group that liked to seize livestock, the citizens' property was labeled as a movement of PKI people. However, if observed carefully, it is not only the property of NU or PNI people who became the victims, there are also many BTI assets that are being targeted by the mob.

The enactment of the PA Law and UU 1963/1964 which took place in several regions as an example, Pilot Project, also triggered conflicts between the PKI and the PNI, because in some villages in Boyolali there are 7 "village devils" and they were PNI members. In February 1964 in the Ketaon there was an incident which killed a youth named Jumeri. The incident was a one-sided action carried out by young people in the struggle for the LoGA and the UUBH against PNI people. PNI people used the power of the Police to drive out the workers, mostly Pemuda Rakyat, which resulted in Jumeri being shot. In addition, the issue of Land Refform and the eradication of Nekolim was brought up by PKI people (interviews with Suparto and Mahmudah). Besides, in the Genting Village, PKI people also took unilateral action by pegging the lands of PNI people after the enactment of the UUPA. Besides pegging the PNI people's land, PKI people also mocked PNI people (Interview with Suparto, September 7, 2019)
Social conflict and looting again occurred in the Boyolali area after the eruption of the G30 S. incident. Conflicts occurred triggered by the existence of conflicting issues that made people restive. The unrest that occurred in this community resulted in some provocation and used by people who previously had individual conflicts. Like or not, but this situation dominates the occurrence of conflict in society. In addition to individual conflicts, there are conflicts that depart from their respective parties. Information received by the community varied from one another to some regions based on PKI, for example, the issue that appeared was that other party people would kill the PKI group, so the community had to hide, and on the contrary in the areas based on NU or PNI, the issues was that the PKI people killed the NU and PNI peoples.

There are some areas that made a fight by cutting down the trees. The felling of the tree took place in the Mojosongo area to Solo to Banyudono. The occurrence of tree felling and burning carried out by PKI people was to prevent the RPKAD movement in carrying out operations against PKI people. In its operations this Patrol never found the person who carried out the logging action and when asking the surrounding community the answer was not knowing. The burning and cutting of the tree was on Friday (Interview with Marno, 25

September 2019)

In Randusari, Teras sub-district based on BTI, the arson of residents' houses was carried out by fake marhaen and intermediaries. Besides that, sweeping of community leaders both the village head and others also occurred. The arson occurred in mid-October 1965 after the tragedy in Jakarta. The Arson also occurred in the village of Tegalsari, precisely in the south of Randusari Village. The arson of residents' houses issue in Randusari was carried out by fake marhaen, but in Tegalsari the arson of reidents' houses issue was carried out by PKI people. In addition to the issue of arson, there were also rumors of an arrest and massacre of PNI people.

On the Friday of October 1965 the operation was carried out by the army in the Selo area. During the operation, the army arrested the BTI figure, Priyo, at the time it was still in celebration of Jagong Bayen. At that time, Priyo, who claimed to have been taken away by the army, was immediately invited to come out, but after a while the gunshot sounded. After the shooting happened, a few minutes later there was a summons from the sub-district to the Muslim youths. It turned out that the call was not only from Muslim youth but also from Pemuda Marhaen who were the volunteers in the operation. In the subdistricts, it was found that YON E and the police had gathered and gave directions that the PKI had carried out a rebellion. 
In Selo area, the community just found out that there were a precarious situation in this area after there was a call by subdistrict to muslim youth who wanted to be trained and volunteered in warfare. There were 42 volunteers and the volunteers were trained for 21 days. The atmosphere of the community panicked and many of them hid in the cliffs. This hiding place is unique, because it turns out that people from the Surodadi village based on the PKI to the north - the Muslim-based Tompak village - are also hiding on the slope of a cliff. From there it was only heard that the issue developing in the village of Surodadi was to carry out attacks which would be carried out by muslim people (Interview with Rukani, 25 September 2019).

The people who volunteered in the operation basically did not know the truth and only guided by the list provided by the army. In the list the names listed are marked in red, green and yellow circles. The target's red circle is killed, green is held and yellow must be monitored by its daily activities. The sign were applied in other areas even tough the models is not the same, but the target is no different, to kill, imprison, and cautious. It was also experienced by Suhardi, when the issue of the maze of killing in the community became increasingly widespread, Suhardi, who was then the village head, was called by the Camat to appear before the police chief. After arriving at the police station, he was presented with a paper containing a list of names with three kinds of marks. There are red mark, cross arrows mark, crosses mark and circled mark. The crossbow mark was the target of killing because he did not know so he asked why it happened to him. The police explained why it was happened to him, because he was considered to people who have cut off relations with the state because he did not attend to the meeting, held in the Sub-district after the meeting in Cepogo District. Because of these events, Boyolali became a city full of national-scale humanitarian tragedies.

\subsection{Psychosocial and Trauma Problems Experienced by Social and Political Conflict Conflicts}

Prolonged conflict in the slopes of Merapi Merbabu has become part of Boyolali's history. In this long conflict, there was an extraordinary violation of human rights. The violations include political and civil rights, socio-cultural rights, alleged killings and extrajudicial torture that occurred during the conflict period. During the conflict from the early 1950s to the end of the 1960s hundreds of people were killed, thousands were missing, hundreds were persecuted, and hundreds of women were raped (Interview with Sugiyo, 7 September 2019).
On the slopes of Merapi Merbabu, the escalation of violence during the conflict began to decline after the end of the suppression of people considered by the PKI and Gerwani at the end of 1968. But the impact of the conflict still remained. One of them is the mental and psychosocial condition of the community. The conflict for almost three decades in Boyolali has at least shown an impact on increasing the number of mental disorders in conflict victims, and dominant traumatic disorders such as PTSD (post traumatic syndrome disorder) and complex trauma that make people vulnerable to live their lives.

When someone had experienced or seen scary events such as accidents, natural disasters, terrorism, the death of a loved one or war, then various kinds of psychological trauma are common. Some people can recover from trauma and resume normal activities. However, for some other people continue to experience trauma so on until it can develop into a post- traumatic stress disorder or posttraumatic stress disorder.

Symptoms of posttraumatic stress disorder can be grouped into four types, namely disturbing memories or instrusive memories, avoidance or avoidance and also emotional numbing or emotional numbing as well as anxiety or increased emotion or hyperarousal. A person can later be diagnosed with posttraumatic stress disorder if several symptoms in each category occur more than one month.

Some of the symptoms that belong to the instrusive memories group include a person experiencing a flashback or an incident that has a returned to a psychological trauma in a few minutes or even up to several days. Someone often remembers the traumatic event and experienced bad things about it. A very deep emotional affliction occurs due to stimuli that signal the event such as a popping balloon that reminds soldiers when fighting on the battlefield, or the date of a traumatic event such as the day he was left behind by a loved one.

Stimulation avoidance is associated with related events or avoidance or numbness in responsiveness is someone who tries to avoid thinking about trauma or dealing with stimuli that can remind about these events which later can cause amnesia to occur in traumatic events experienced. Numbness is a decrease in interest in others, feels like being separated and also unable to feel all the emotions in positive psychology. Some of these symptoms will look the opposite of symptoms in the first group. But in reality, there are fluctuations in which the sufferer will alternately experience a return and also numbness. Symptoms of anxiety as well as increased arousal, tension or emotion include difficulty sleeping, difficulty concentrating, being overly alert and being overly surprised. 
Other problems that are often associated with posttraumatic stress disorder are other anxiety disorders, anger, depression in psychology, guilt, substance abuse with the aim of self- medication so that distress can be eliminated, marital problems, sexual dysfunction, decreased physical health and also decreased productivity in work. Suicidal thoughts and plans are also very common, as is the incidence of a loud explosion and psychophysiological problems related to stress, headaches, lower back pain and digestive system disorders The clinical picture of posttraumatic stress disorder or signs of depression in children is also different from adults. Sleep disturbance accompanied by nightmares about monsters are also very common, including changes in behavior. For example, a child who was originally a happy child, suddenly becomes a quiet child and withdraws or a child who is initially quiet turns to be aggressive and rude. Some children who experience a traumatic event think that they will not be able to live to adulthood. Some children can also lose development skills that are actually already mastered such as writing, speaking, using the toilet and so on. Children will be more difficult to express about the feelings they experience compared to adults.

A woman who in 1965 was 7 years old named Sutini suffered a mental disorder after her father Supardio became a victim to stabbing until he died in the event of the drilling and he could save himself without any injury. After going through a period of mourning, her condition began to looks normal. However, two years after the murder suspect was captured, the girl began to repeatedly experience nightmares and also begin to remember the memories of the crime. In the dream, he saw blood and himself being chased by someone who threatened with a closed face. During the day especially when walking alone, he often daydreaming that she forgot her purpose.

Her friends who noticed said that she was very easily surprised and always worried about something. She often left change or groceries at the store and also often could not remember what items to buy. The person also begins to feel anxious and her work becomes disturbed because she cannot concentrate. Slowly he began to withdraw from his friends and began to avoid the work she had. She also felt very guilty about her father being murdered incident even though it was unknown why this could occur (Interview with Ginah, 7 September 2019).

In 1966, Sapon was invited by her husband to evacuate on the slopes of Mount Merbabu because the Sapon family felt unsafe living in their villages because there were rumors of murder to even innocent people. Nearly 3 years Sapon and her husband lived on the slopes of Mount Merbabu. In 1969 Sapon and her husband returned to their hometown. Returning to his hometown Sapon initially looked fine. But a year later suddenly Sapon changed, became angry without cause. Every time he saw people who came to his house scolded, and Sapon really hates his neighbor named Todiwiryo. Finally, Sapon completely lost his memory until his death four years later (Interview with Asmui, 8 September 2019).

\subsection{Trauma Healing That Has Been Received}

Trauma recovery can be done in two ways: individually and in groups. In many cases trauma recovery is more effectively done as a group. There are several efforts that can be done to help recover from trauma quickly and easily, namely individually: chatting, listening to complaints, motivating individuals to do activities. The family provides support that can comfort family members who feel lost in conflict. For the community, debriefing can be done after a disaster event, developing a support group, or developing a self-help group.

Rothbaum [10], states recovery treatment for prolonged trauma (Prolonged exposure) through cognitive therapy is more effective than selected drugs such as reuptake erotonin or rather than no recovery treatment in preventing post-traumatic stress disorder [16]. In addition, he also stated that the treatment and prevention of PTSD can be done by removing fear, from traumatic stimuli by replacing them with other stimuli.

To escort the trauma victims due to violent warfare stated by Stradling, there are several aspects that can be done, namely: First, increase sensitivity, recognize the symptoms of trauma in people around, take a gentle and compassionate approach, empathy, act cautiously, offer referral assistance to professionals. Second, professional responses (psychologists, psychiatrists, and counselors) to help trauma survivors related to: (1) incident Stress Debriefing (CISD), (2) retelling of traumatic events experienced structurally in the period 24-72 hours after the occurrence of traumatic events, (this matter, is still debated whether good to be used / not), (3) stress post-trauma stress, (4) normalization of reactions, (5) help the coping process [17].

In cognitive therapy, therapists help to change irrational beliefs that interfere with emotions and interfere with activities. For example, a victim of crime might blame themselves for not being careful. The cognitive goal of therapy is to identify irrational thoughts, gather evidence that those thoughts are not rational against these thoughts which then adopt more realistic thoughts to help achieve more balanced emotions.

Meanwhile, in exposure therapy therapists help deal with specific situations, other people, objects, 
memories or emotions that are reminiscent of trauma and cause unrealistic fears in their lives. Therapy can work by: exposure in the imagination, which is asking the patient to repeat the story in detail until it does not experience obstacles to tell; or exposure in reality, which is to help deal with the situation that is now safe but want to be avoided because it causes a very strong fear (for example: returning home after a robbery at home). Fear is stronger if we try to remember the situation rather than trying to forget it. Repetition of the situation accompanied by repeated awareness will help to realize that the past terrifying situation is no longer dangerous and can be overcome.

In addition, play therapy can also be found to be useful in healing children with PTSD. Play therapy is used to treat children with PTSD. Therapists use the game to start topics that cannot be started directly. This can help children feel more comfortable in processing their traumatic experiences. Debriefing therapy can also be used to treat traumatics. Although there is a lot of controversy about debriefing both in the general PTSD literature and those led by midwives.

Judging from the way individuals or groups handling trauma due to conflict on the slopes of Mount Merapi Merbabu is mostly done in groups. In carrying out the wheels of government of the Boyolali Regency Government bring together people who are in conflict in various forums. A forum that serves to determine the recovery of trauma in the Boyolali people. In addition, the program launched by President Soekarno with the slogan of unity and unity must be able to color the lives of the people. It can even be socialized at the grassroots level. In addition there were also relations between major parties winning the 1955 elections including the PKI, PNI, NU and Masyumi united in the National Front.

Forums or fronts that function as media sit parallel to determine development policies and address Boyolali socio-political issues that can be applied to the village level even though the names are not the same. In every discussion that is held very democratic despite differences, the logical argument that goes forward is not the muscle fighting used. In Desapun, the democratic tradition has been running well because in every determination of village development, it is not directly handled and decided by the village head himself but must get agreement from the National Front. Apart from the front, there must also be an agreement from the people involved in the village administration such as Bamusdes, RT, RK and DPD (Village Development Council). In determining village policies, most lurahs also always involved forums that consisted of various parties and this decision became a reference in conducting village governance (Interview with Suparto and Supardiyo, 7-8 September 2019). Whereas the trauma victims after the G30S Boyolali
Government called for volunteers, both doctors and non-doctors, to help the people who were traumatized for their recovery. The method that often used is the method of speaking. The victims of the conflict were asked to speak as much as possible, then asked to slowly forget the events they had experienced. Drug therapy is also carried out. This is stated in trauma patients who are already acute. They were given sedatives in the control of doctors and volunteer medical personnel.

However, according to several sources, the government's efforts in recovering the trauma of the Boyolali community due to social conflict were felt to be less successful. Many people are still afraid and suspicious of each other (Interviews with Suparto, Supardiyo, Ginah and Mahmudah 7-8 September 2019). According to them, the residents tried to recover from the trauma and mental disorders experienced by their relatives and neighbors. How, they often visit, invite to chat and sometimes bring souvenirs. This is felt actually helps a lot reduce the anxiety of people who experience mental stress.

There are also a number of non-governmental organizations that came to help by providing various kinds of recovery assistance, including by giving advice, medicines and food. However, most residents are suspicious of the consequences behind the various gifts. Residents still trust their relatives more than others who are new to them, even when conflict is involved, it is not uncommon for conflicts with relatives and neighbors themselves. However, residents' trust in relatives and neighbors is certainly not relatives and neighbors who have been involved in conflict. Therefore, the problem of trauma due to social conflict in the slopes of Merapi Merbabu Boyolali can be said to have not been resolved properly and completely. It seems necessary to have a special model that is well planned and involved various parties to overcome the trauma of the Merapi Merbabu slope community that has been chronic and there is a hereditary tendency. From the interviews the researchers did with several informants, their problem was not only trauma due to social conflicts but also the gloominess of their views on their future. They feel that since their elders have always been defeated by officials, employees and wealthy people or city people in their terms (Interview with Ginah, 8 September 2019).

Thus they also want to be certain of their rights and their work and future. For them, land is a living hanger, while many rich people have bought land around their homes. They worry that someday their lands will also be bought by various persuasions of rich people. Thus, a government that is strong and protects the people is always what they want. 


\section{CLOSING}

\subsection{Conclusions}

Based on the results of research and discussion in chapter 4 above, it can be concluded as follows:

1. Communities in the slopes of Mount Merapi and Merbabu experienced prolonged conflict for almost three decades. Starting from the chaos caused by the Suro Bledek (Suradi Bledeg) movement and friends, comrades, then the Merapi Merbabu Complex group who often robbed, orchestrated and edited, and social conflicts before, during and after the G30 S. This long social conflict has brought victims countless lives and possessions.

2. As a result of prolonged social conflict, people in the slopes of the Mountain Merapi and Merbabu had experienced psychosocial problems and trauma. They become irritable, are resistant, anxious without cause, feel pursued by events that have endured, alienated themselves and even some including to be forgetful or crazy.

3. Various parties, both the government, nongovernmental organizations or the community it self has made various efforts to restore the people of the slopes of Merapi Merbabu who experienced psychosocial problems and postconflict trauma. Will but so far the efforts of trauma recovery have been carried out by various the party is not considered to have brought the expected results.

\subsection{Suggestions}

Based on the above conclusions, it is advisable to conduct more in-depth research and prepare a comprehensive and accurate model to assist in the recovery of trauma after social conflict in the Merapi Merbabu slopes. The model meant not only to recover trauma from the past but also to provide psychological assurance for their bright and restful future and not feel haunted by the bad conditions that might occur.

\section{REFERENCES}

[1] Fahmi, T., \& Akbar, M. Z. : Pemetaan daerah rawan konflik sosial di Kabupaten Tanggamus. Jurnal Sosiologi, 17 pp 114-116 (2015), Neumeyer, H : Unity in diversity or diversity in unity: Indonesia's process of political decentralisation and its effects on conflicts. Law and Politics in Africa, Asia, and Latin America, pp. 39 (3) (2006), Schefold, R :. The domestication of culture; Nation-building and ethnic diversity in Indonesia.Bijdragen Tot de Taal-,LandEn Volkenkunde/Journal of the Humanities and Social Sciences of Southeast Asia. pp 154 (1998)

[2] Fahmi, T., \& Akbar, M. Z. : Pemetaan daerah rawan konflik sosial di Kabupaten Tanggamus. Jurnal Sosiologi, 17 pp 114-116 (2015), Bräuchler, B. :
Cultural Solutions to Religious Conflicts : The Revival of Tradition in the Moluccas, Eastern Indonesia. pp 37 (2009)

[3] Kesbangpol.: Pelaksanaan Koordinasi Penanganan Konflik Sosial. Kemendagri. Jakarta. pp 2-3 (2015)

[4] Suseno, F. M. : Etika sebagai kebijaksanaan hidup: Catatan tentang Struktur Etika Jawa. dalam Suseno, F. M., \& Reksosusilo, S. Etika Jawa dalam Tantangan: Sebuah Bunga Rampai.). Kanisius, Yogyakarta. pp 2122 (1983)

[5] Mulder, N. : Abangan Javanese Religious Thought and Practice. Journal of the Humanities and Social Sciences of Southeast Asia. Vol 139 (2/3). (1983)

[6] Suseno, F. M. : Etika sebagai kebijaksanaan hidup: Catatan tentang Struktur Etika Jawa. dalam Suseno, F. M., \& Reksosusilo, S. Etika Jawa dalam Tantangan: Sebuah Bunga Rampai.). Kanisius, Yogyakarta pp 2122 (1983), Wahyono, Kejawaan dan Keislaman: Satu Pertarungan Identitas. Jurnal Ilmu Sosial dan Ilmu Politik, 5 (1), 5 pp 4160.https://doi.org/10.22146/jsp.11107, (2001).

[7] Tjosvold, D., Chen, Y., \& Yu, Z. Conflict Management for Individual Problem Solving and Term Innovation in China. Journal of Working Paper. pp 2-44 (2003)

[8] Meffret,S.\&Ekblad,S. : Global Mental Health Intervention Research and Mass Trauma. Open Access Journal of Clinical Trials. Vol 5 (2013)

[9] Macy, R. D. Behar, L. Paulson, R. Delman, J., Schmid, L \&Smith, S. F.: Community-base, Acute posttraumatic stress management: A Description and evaluation of a psychosocial- intervention continuum. Harv. Rev. Psychiatry. Vol 12 (4) (2004)

[10] Alexander, Jeffrey C. , Ron Eyerman, et.al.: Cultural Trauma and Collective Identity. University of California Press. Oakland. pp 1-10 (2016)

[11] Waterson, Patrick. : A critical review of the STAMP, FRAM and Accimap systemic accident analysis models, in Advances in Human Aspects of Road and Rail Transportation. CRC Press. Boca Raton. pp 285394 (2012)

[12] Gordon, Paula.: Solid Breast Masses Diagnosed as Fibroadenoma at Fine-Needle Aspiration Biopsy: Acceptable Rates of Growth at Long-term Follow-up1 in Jurnal Radiology 229(1) pp 233-8 (2003)

[13] Rothbaum BO et al. : Early intervention may prevent the development of posttraumatic stress disorder: A randomized pilot civilian study with modified prolonged exposure. Biol Psychiatry 2012, Dec 1; 72 pp 957 (2012)

[14] Goleman, Daniel. Emotional Intelegence: Mengapa EI lebih Penting dari IQ. Gramadia Pustaka Utama, Jakarta. pp 77-78 (1995) 
[15] Baranowsky, Anna \& Teresa Laure. What Is PTSD? 3 Steps to Healing Trauma, Kelly Patton, LMHC, http://www.KellyPatton.com ,Live Your Life On Purpose! Tampa/St. Pete FL. Pp 21 - 40 (2012)

[16] Rothbaum BO et al.: Early intervention may prevent the development of posttraumatic stress disorder: A randomized pilot civilian study with modified prolonged exposure. Biol Psychiatry 2012 Dec 1 72. pp 957 (2012)

[17] Hatta, Kusmawati. Trauma dan Pemulihannya Suatu Kajian Berdasarkan Kasus Pasca Konflik dan Tsunami. Dakwah Ar- Raniry Press. Banda Aceh. pp 115 (2016) 